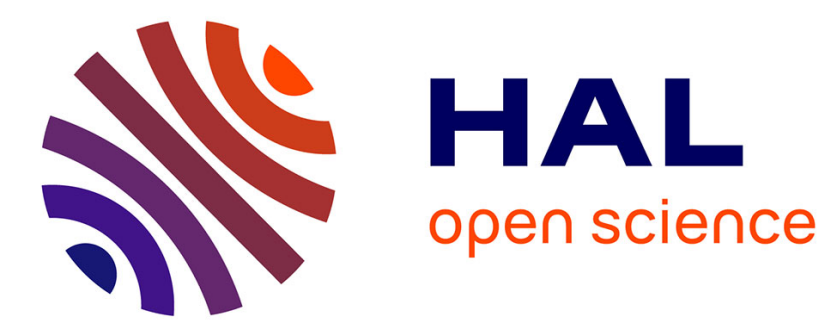

\title{
The changing landscape of publishing in Nepal: Interview with Bidur Dangol
}

\author{
Bidur Dangol, Mark Turin
}

\section{To cite this version:}

Bidur Dangol, Mark Turin. The changing landscape of publishing in Nepal: Interview with Bidur Dangol. Book 2.0, 2019, 9 (1-2), pp.83-91. 10.1386/btwo_00008_7 . halshs-03083470

\section{HAL Id: halshs-03083470 \\ https://shs.hal.science/halshs-03083470}

Submitted on 22 Jan 2021

HAL is a multi-disciplinary open access archive for the deposit and dissemination of scientific research documents, whether they are published or not. The documents may come from teaching and research institutions in France or abroad, or from public or private research centers.
L'archive ouverte pluridisciplinaire HAL, est destinée au dépôt et à la diffusion de documents scientifiques de niveau recherche, publiés ou non, émanant des établissements d'enseignement et de recherche français ou étrangers, des laboratoires publics ou privés. 


\title{
INTERVIEW
}

\author{
BIDUR DANGOL
}

Vajra Books and Vajra Publications

\author{
MARK TURIN
}

The University of British Columbia

\section{The changing landscape of publishing in Nepal: Interview with Bidur Dangol}

Mark Turin (MT): Please tell me a little about your background. When were you born and where did you grow up? Was education important to your family?

Bidur Dangol (BD): I am from Nepal, a small landlocked country in the northern reaches of South Asia, located between two regional giants, India and China. Nepal is extremely diverse in terms of culture, language, religion and landscape. I was born and raised in a traditional Newar family in the beautiful and historic Kirtipur, located on a hill in the south-west quadrant of the Kathmandu Valley. Kirtipur is considered to be one of the most ancient

\section{KEYWORDS}

Nepal

Kathmandu

Himalaya

e-commerce

digital

publishing cities and civilizations in the Kathmandu Valley, and one of the most historically important sites for the unification of Nepal. The Gorkha King, Prithvi Narayan Shah, finally conquered the city in 1767 during the Battle of Kirtipur. Our strategic location on the top of a hill with views all over the city, combined with the resolve of the Kirtipurians to defend their livelihoods, meant that Prithvi Narayan Shah was only able to annex the city on his third attempt, and 
he exacted his revenge on the citizens in ways that are still remembered and talked about.

The traditional and historical - we might say Indigenous - inhabitants of Kirtipur and in fact the entire Kathmandu Valley are the Newar community, although things have changed vastly on account of globalization and the valley is now very diverse with all of Nepal's communities represented. Within the Newar community, the principal inhabitants of Kirtipur have always been members of Maharjan or Dangol caste, to which I belong, and we are followers of Buddhism.

I was born in 1964, into a huge joint family with very limited financial resources, so my upbringing and childhood was tough and full of challenges. Agriculture was the major source of income for most of our community at that time, as it was for my family, but my father also ran a small pharmacy to generate some extra income. There were only two schools in Kirtipur in the 1970s, both of which were government schools: the Laboratory Secondary School and Janasewa Madhyamik Bidhyalaya. I completed my schooling at Janasewa Madhyamik Bidhyalaya, and was one of very few in my cohort to have passed the School Level Certificate. I have to say that the quality of education was really quite poor, which could be seen from the low number of students who graduated from our school every year.

At that time, many people didn't send their children to school. Most people in our community didn't understand the value of education as most were illiterate themselves and had very limited financial resources. Although my parents were also illiterate, they realized the importance of education very early in life, and believed it was essential to educate their children. Somehow my father managed to ensure that my siblings and I were educated, which we are hugely grateful for to this day. After school, I even went to college to pursue a higher education. Up until this point, I had never been introduced to even the basics of the English language. There were no books at all in my house, as my parents and grandparents were not readers. It was only after completing my schooling that I started working, and then planned to open a bookstore with my brothers. My eldest brother, Madhav Lal Maharjan, had worked at a shop called Nepal Book Seller located on New Road in the centre of Kathmandu, so he already had a great deal of relevant experience in the book industry before I started. New Road is near the alternative and hippy tourist area known as 'Freak Street', which meant that the store had a lot of foreign clients. Even during my teenage years, my brother would take me to visit the bookstore, which is where my inspiration came from. Having gained valuable experience there, my family started Himalayan Book Seller, a bookstore at Ghantaghar. I am particularly grateful to my eldest brother, Madhav, who used his experience to help us to establish our own bookstore. I was fortunate to learn much from him.

MT: You are now one of Nepal's foremost English-language book publishers and distributors. You have made something of a switch from book selling to book producing and publishing. How did that come about, and how different is it a model? What was the first book that you published?

BD: I have been in the book trade since 1984, when my siblings and I ran a small book store in Thamel, near the Kathmandu Guest House, called Kathmandu Book Shop. One of my fondest memories of the 1980s was when the 39th President of the United States, Jimmy Carter and his wife Rosalynn 
visited my book store. At that time, we also had another small branch at Ghantaghar. In 1989, I moved to Mandala Book Point which was one of the biggest book stores in Nepal at the time, and that was when I learned the most about the book industry. Before 1989, Mandala Book Point was called simply Book Point, and was owned and operated by my eldest brother, Madhav. In 1989, when all three brothers started working as a partnership, we renamed it Mandala Book Point and I managed the shop until I left to start Vajra Books in 2003. It was during my formative time at this bookshop that I was first introduced to the scholars, researchers, mountaineers and other friends of Nepal people who are friends of mine up to the present day.

After Nepal became a democratic nation in 1990, a conference was held in Kathmandu hosted by the Centre for Nepal and Asian Studies (CNAS) at Tribhuvan University in Kirtipur - coincidentally the city that I am from at which I first met a number of the most influential foreign scholars of the Himalayas, including: Michael Opitz, Charles Ramble, Michael Allen, FranzKarl Ehrhard and many others. I was introduced to these scholars by Professor Eberhard Berg from the University of Zurich in Switzerland whom I also met at the same conference. I recall these meetings because they were so formative for me, and also because these scholars went on to become friends and eventually authors I would publish. After the democratic movement of 1990, the press and the publishing business blossomed, and I feel very fortunate to have been part of that development.

In 2003, I moved out of Mandala Book Point - our family business - and decided to open Vajra Books. This was a big step for me personally and for my family. I decided to open my own shop because I wanted to move out of my comfort zone and be more independent. Starting my own store would also mean being able to work more freely, develop my own ideas, and generate more income to support my immediate family. Vajra means thunderbolt, a weapon used by the Hindu god, Indra, but it also has significance in Buddhism. My main intent behind naming the shop Vajra was that it would focus mostly on Himalayan Studies and Buddhism, which was my clear goal and focus when I decided to go independent.

The first few years were really tough, as I had to start from the beginning all over again. There were times when I questioned whether leaving Mandala - the established family business - was the right decision. During the first few years, I worked long hours and went to the shop every single day in order to build up the relationships, credibility and brand. I think that a combination of my many years of experience in the book trade and publishing combined with hard work and a deep passion for books made it possible for me to overcome the challenges, and I am delighted that I've been able to establish Vajra Books both nationally within Nepal, and more recently internationally as an important publisher and distributor of books about the Himalayan region as a whole.

One of my biggest dreams since entering the book trade was to launch my own imprint and actually publish books, and to develop an international distribution network for these publications about the Himalayan region. Even dreaming of such things was a big thing back then, because of the constraints on publishing and Nepal's limited exposure to international markets and distribution channels. It really helped that I was well-connected with a number of foreign scholars working in Nepal, Tibet, Bhutan and India before I launched Vajra Books, and it is these scholar-friend-authors who have been very supportive of what I have built. 
I realized my dream of becoming a publisher in 2004 with the publication of Martino Nicoletti's book Riddum: The Voice of the Ancestors which you, Mark, reviewed for the Nation Weekly (Nicoletti 2004). Since then, I've published over 200 titles, and the authors who chose to work with me have demonstrated their trust in the approach that I have taken. I believe that when you're in the book trade, there's no motivation bigger than having the trust of an author. While the book business isn't the most profitable sector, it rewards you with goodwill and good ideas,

MT: I see from your catalogue that the books that Vajra publishes are mostly in English. Why is that and do you also publish in other languages?

BD: Vajra mostly specializes in Buddhism, Himalayan studies, history, anthropology and cultural studies. Most of my customers are international students and scholars, and the same may be said of my authors. Since the majority of the foreigners who visit my store and research or live in Nepal speak English more than any other language, my primary focus has been on producing English language publications to connect with this scholarly community. Also, given the location of my bookstore in Thamel, an important tourist location, I have found it helpful to focus most of my attention on publications in English. Even my local customers read and write English well, so the choice of language doesn't create issues. In addition, most of my publications have a good market and distribution in the West where English titles are widely approved by the international distributors and book stores in a way that local languages are harder to make the case for.

Besides English, I also publish works in Nepali, French, and Tibetan. I've published about ten books in the Nepali language, most of which are fiction. Similarly, I've published over twenty French and Tibetan titles. Over time, I have felt the need to publishing in French on account of the increasing number of French tourists and scholars in Nepal and I am delighted to report that I've received really good responses about all the titles that we've released to date. For the French titles, I mostly focus on manuscripts related to Nepal, while the Tibetan language books are mostly for very specific readers, namely Tibetan Buddhist monks and scholars of the Buddhist tradition.

MT: I recall that for some time, books published in Nepal were not easily accessible outside the country. Has this changed now and what role has the Internet played in the distribution and dissemination of your publications?

BD: You're quite right: things were difficult and they have improved a great deal. When I started in the book trade, it was really tough to connect with our potential global readership unless they actually came to Nepal and walked into one of our shops. In the past, thanks to the lack of proper communication tools and challenges in international payment systems, books that we published and printed in Nepal couldn't be distributed out of the country. But now things have changed for the better, and the change has been profound.

The Internet has changed not only the way that we communicate but also how we do business. In particular, the Internet has transformed the book business in Nepal, as readers can now directly purchase books from our website and they will be delivered directly at their doorstep anywhere in the world within ten to fourteen working days, or even quicker if the user pays extra for express shipping. We now have our own distributors in Europe and other parts of the world with the result that the global market for books published 
in Nepal has increased dramatically and our publications are reaching readers and libraries in places that they wouldn't have before. I was lucky to have been introduced to the Internet by a friend at a very early stage and took to e-mail instantly, realizing its power to connect across time and space. Early obstacles were simply the cost of purchasing a computer, as hardware remains expensive in Nepal. However, I managed to purchase a small laptop in 2004, and have moved from simply answering e-mail requests to maintaining and updating Vajra's dynamic website. Another obstacle was finding a reliable and speedy payment system, and in the past this gave us a real headache, with payments taking months to arrive. Now it's just a matter of days for a bank wire, or even shorter through PayPal. These digital and online e-payment systems have had an impact for all international-facing businesses in Nepal, the book industry included.

MT: As a publisher, you need to consider many different aspects of the intellectual work and the business model. Do you do all of the work in-house (copy editing, design, layout, proofing, printing) or do you work with partners in the book industry in Nepal?

BD: We have been working with Dongol Printers since we started, they are our relatives and have also been in the book trade for over 30 years now. On their staff, they have a team of experts who manage all aspects of design, layout and printing, and I would say that they are some of the most reliable, professional and committed people in this business. We always communicate back and forth with the author till everyone is satisfied with all aspects of the layout and formatting. On occasion, I have had dealings in India for higher quality printing jobs that are still not possible in Nepal. The quality of and technology behind book printing is a lot more advanced in India, and you can really see the difference with hardback binding, whereas in Nepal we can't really compete with our regional neighbours.

MT: Academic publishers in the Global North have high profile editorial boards and send manuscripts out for review. Do you also do that? Have you ever rejected a submission or do you always publish if an author brings funds to the table? And in that vein, would you consider yourself an academic publisher or trade publisher?

BD: We don't have an editorial or advisory board as such, but I do consult with my scholars and published authors to offer advice about manuscripts and to help with editorial work, as needed and depending on their expertise. When I first started publishing, we didn't send manuscripts out for review, but now we do review most academic and fiction submissions.

I would consider myself to be an independent academic publisher. As an independent publisher, it can be financially challenging to publish a book since costs are high and sales are often modest. On receipt of a manuscript, I always first explore whether it fits my area of expertise and subject matter. If it does, I'll proceed accordingly. And it certainly does help a lot if authors can find publishing subventions and resources to help cover the costs associated with production. These kinds of partnerships help us to produce quality publications.

MT: For many scholars whose work focuses on Nepal, there is a strong incentive to publish outside of Nepal for reasons of promotion, tenure and academic advancement. Some have struck creative deals with publishers in the west to release South Asian 
editions. Does Vajra support South Asian publication deals with foreign presses, or does Vajra seek publishing arrangements for your books to be co-published abroad?

BD: International scholars have until recently published outside of Nepal for reasons of promotion and on account of lower production quality in my country. I'm really glad to say that these obstacles are not so great anymore. We can now produce books of world-class quality in Nepal too and are distributing our publications across the globe. We are also active on social media, where we are able to connect with many scholars and students, thus participating in important academic conversations.

Regarding South Asian editions, we have in the past purchased the rights from some international publishers to be able to print and distribute local editions that match our interest and expertise. For instance, we've published South Asian editions of titles from the Dutch publisher Brill, from the Japanese National Museum of Ethnology in Osaka and others. We've also struck a deal with Routledge regarding the distribution a selection of their list for exclusive distribution by Vajra Books in Nepal.

I have noticed the following: for books published in the West in what we may call Nepal or Himalayan studies, the largest market is within Nepal itself. At the same time, for the book to sell, it has to be affordably priced and published in a South Asian edition. In my experience, customers - both locals and foreigners - often aren't willing or aren't able to pay the cover price of the original edition which can easily run into the hundreds of dollars. I believe that if these books were to be originally and first published in Nepal, the market would be even bigger.

Alongside new and innovative manuscripts that are submitted for consideration to Vajra Books, and a number of South Asian editions of books first published abroad, I also re-publish classics that I believe are particularly important for my country. Of course, I only commit to reprints after receiving the consent from the author and original publishers. A recent example of a hugely important contribution is the two-volume Kathmandu Valley: The Preservation of Physical Environment and Cultural Heritage; a Protective Inventory originally published by Anton Schroll together with UNESCO in 1975, and painstakingly prepared by the Nepal Department of Housing, Building and Physical Planning together with Carl Pruscha. After the catastrophic earthquakes that rocked my country in April and May 2015, damaging or destroying hundreds of unique and ancient temples across Nepal - and many in the Kathmandu valley - I felt that republication of this masterpiece was more important than ever. Since the book had been out of print for many years, I wrote to UNESCO who were not only very positive about the re-release of the book, but were even willing to offer some financial assistance to make sure that it was available on the market as quickly as possible and that the many pages of beautiful plates were of excellent quality. I am delighted to see that architects, planners, heritage workers and scholars of art and history have shown great interest in the re-release of this unique publication. Another book that I felt needed to be available in Nepal was Man and his house in the Himalayas: Ecology of Nepal by the French anthropologist Gérard Toffin. First published by Sterling Books in New Delhi, India, in 1991, this exceptional study of vernacular regional architecture, mostly farmhouses, documented a style of building and design that was gradually disappearing. This disappearance was accelerated by the earthquakes of 2015 and the governmentsanctioned and earthquake-proof designs that are now compulsory during 
this period of reconstruction and rebuilding. Toffin and Pruscha's books are powerful visual records of our shared past, much of which is now lost. Both books have generated a lot of interest and are selling well.

There are other architecture books that I have in mind for republication, and I have already secured the necessary permissions from the authors. As a citizen of Nepal, and of the Kathmandu valley in particular, I believe that it's very important for publishers to play a role in the documentation and preservation of our shared cultural heritage. But as always, there are risks in taking on such projects - sales are not certain and printing costs are high - just some of the problems that an independent publisher has to face in a country like Nepal.

MT: Why would someone choose to publish with you rather than with another press in Nepal? What service and skills do you bring to the table that make Vajra so attractive to many international authors?

BD: Authors expect quick and reliable service, and high quality publications, and we're focused on that. I also believe that open and effective communication between the two parties - author and publisher - is vital in order to work in a trusted manner and achieve our common goals. If an author is not resident in Nepal, we keep in very regular communication by e-mail until the final draft is ready to go into layout. For those who are in Nepal, or who come regularly, we encourage authors to visit our design team and work side-byside with them at their office if they can.

This whole industry is predicated on relationships and trust, and we find that many of our new authors are referred to us by existing authors who have had positive experiences. On publication, our authors also expect that their work will be distributed all around the world, and Vajra is able to commit to this with our global distribution network. Of the Nepal-based publishers, I believe that we are unique in offering most of our titles as Kindle e-books as well, and we're the first publisher in Nepal to embrace this opportunity. Amazon is a powerful marketing tool for publicizing our list, and I find that their platform has one of the best search engines across all of the e-commerce sites, so we're quite committed to selling books through Amazon and have been for some years now. Once again, these global networks and digital distribution channels have really helped the publishing business in Nepal which had excellent and unique content which was effectively restricted to people in-country until now.

MT: I have noted the huge improvement in production quality in terms of what can be printed in Nepal. What have been some of the most important developments from your perspective over the last few years?

BD: I agree, we have improved immensely in the quality of our book production and printing. The difference can be seen most clearly when comparing our latest publications to our first titles. The greatest improvements have been in the quality of the binding, paper stock and the nature of the printing itself. We now have a wide selection of different paper stock to choose from for every type of book. In the past, one of my principal concerns was the longevity and quality of the binding, and I am very happy that it has improved a lot when compared to what we used before. Having said all that, we still have considerable room for improvement if Nepal is to meet an international standard of printing and 
binding. While using the newest technology gives a printing house a competitive advantage over others, the reason that it takes time for new technologies to arrive and take root in Nepal is because of the skills required to operate the system and high costs we incur to repair such machines as they have to be shipped all the way to the dealer because of the lack of technically skilled people in Nepal who can service and repair them. These frustratingly practical challenges are the primary reason that Nepal is still slightly behind other countries when it comes to printing technology and quality.

MT: What do you make of the movement towards open access publishing, both for journals and for monographs? What does it mean for a publisher like Vajra?

BD: Open access publishing is not something that many publishers in Nepal can commit to, mainly because the costs have to be borne by independent publishers themselves and we don't have easy access to grants from external entities like foundations and research councils. However, we have signed contracts with authors and organizations in the past where we've agreed to the open access release of specific titles when these have been partially funded. I still think that most of our readers prefer physical books in print form. One interesting example of a blended model is that we've published seven books from the Chödung Karmo Translation Group which was founded in 2010 at the International Buddhist Academy in Kathmandu, Nepal, to help fulfil the late Khenchen Appey Rinpoche's vision for the preservation and transmission of the Buddha Dharma. The group is committed to translating the classics of the Sakya Buddhist tradition, and chapters from these books are also made available freely available on their official website to benefit their followers and practitioners: https:// chodungkarmo.org/publications/. This is one example of a specific arrangement, but as I said earlier, as an independent publisher, fully embracing open access would result in a profound loss of business for us.

MT: What is next for you? What are the current challenges and where would you like to go from here?

BD: My current challenge is to make each new publication better than the previous one in terms of quality. I'm now focusing on more coffee table books and more studio work. I'm particularly excited about the quality of the image plates that we're now able to publish. My aim is to attract more international scholars and photographers to choose Vajra as their publisher. Since it's not possible to produce works of the highest quality in Nepal at present, I've had to travel abroad for some of my recent publications in order to ensure the highest quality and not compromise on my expectations.

I have recently published books from scholars and photographers whose work was previously published by some of the most highly regarded publishers in the world. For instance, I've just published Mustang in Black and White with photographs by Kevin Bubriski and text by Sienna Craig. Kevin is an extraordinary photographer whose work is found in the permanent collections of the best museums in the world, and whose Nepal 1975-2011 was published by the Peabody Museum Press and Radius Books in 2014. Sienna is an anthropologist and poet, whose earlier monographs were published by the University of California Press and Wisdom Publications. I am delighted that these authors chose Vajra as the publisher for their book. 
It has been a pleasure to be able to work with and learn from some of the very best scholars in their particular disciplines from around the world, and to have developed not just professional author-publisher relationships but also enduring friendships over the years. I am excited for the next chapter, and thank you for taking the time to ask these questions.

MT: Thank you, Bidur. It has been a pleasure and I too have learned a lot.

\section{ACKNOWLEDGEMENTS}

The contributors are very grateful to Lokesh Dangol for his assistance in reviewing the interview questions and answers.

\section{REFERENCE}

Turin, Mark (2004), “In their own words" review of Riddum: The Voice of the Ancestors by Martino Nicoletti', Nation Weekly, 1:31, p. 57.

\section{CONTRIBUTOR DETAILS}

Bidur Dangol is Managing Director of Vajra Books and Vajra Publications, in Jyatha, Thamel, Nepal.

E-mail: bidur_la@mos.com.np

Mark Turin is an anthropologist, linguist and occasional radio presenter, and an associate professor of anthropology at the University of British Columbia, Vancouver, Canada. He has worked in the Himalayan region (Nepal, Bhutan, northern India and Tibet) since the early 1990s, and is the author or co-author of four books, three travel guides, the editor of nine volumes, and he edits a series on oral literature. He tweets @markturin.

E-mail: mark.turin@ubc.ca

- http://orcid.org/0000-0002-2262-0986

Bidur Dangol and Mark Turin have asserted their right under the Copyright, Designs and Patents Act, 1988, to be identified as the authors of this work in the format that was submitted to Intellect Ltd. 


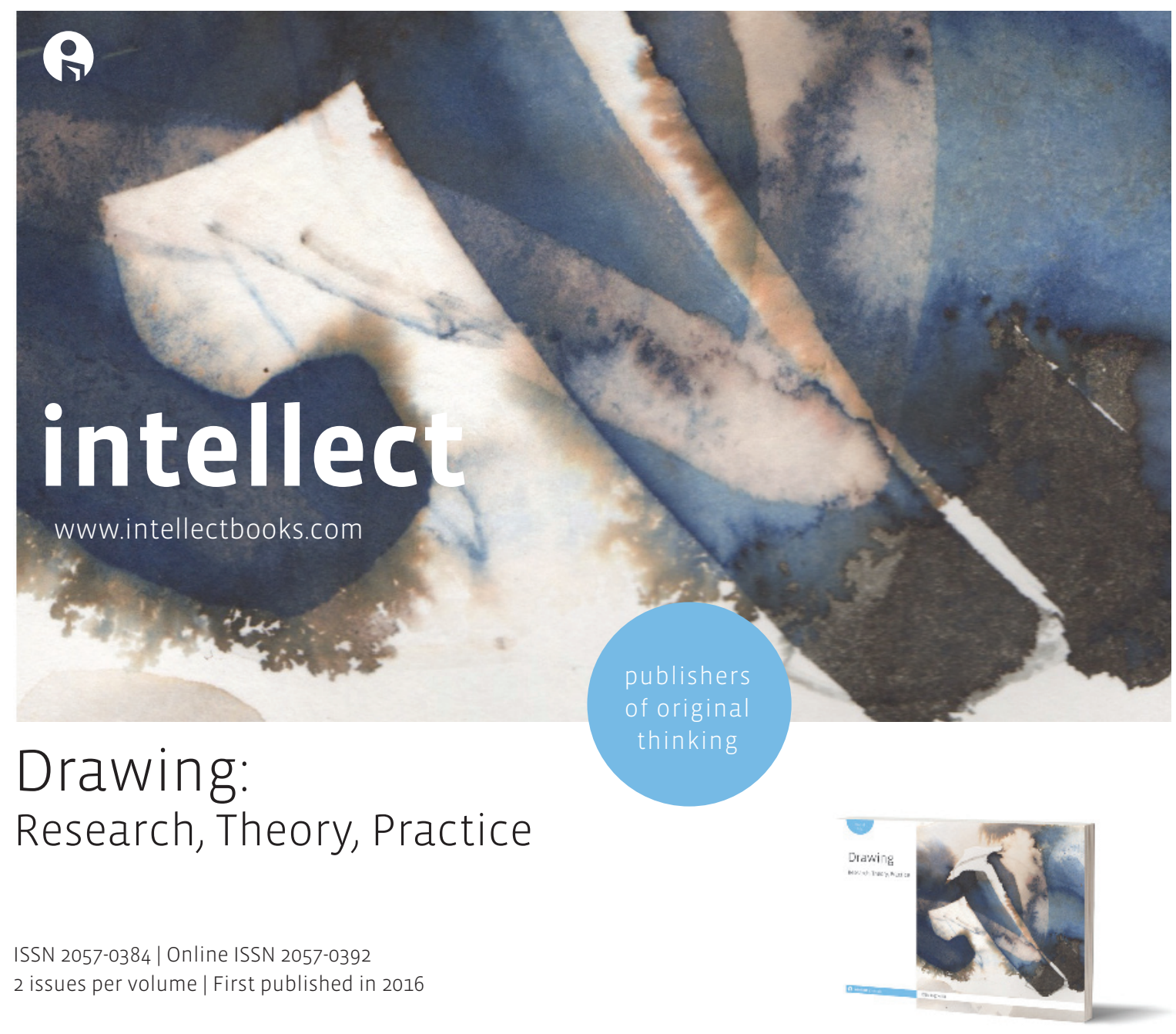

\section{Aims and Scope}

Focusing on drawing as a significant discipline in its own right, Drawing: Research, Theory, Practice facilitates ongoing international debates within the wider fields of its practice and research. A vibrant, proactive forum for contemporary ideas, the journal is a platform for interdisciplinary and cross-cultural dissemination of all forms of drawing practice and theory.

\section{Call for Papers}

Drawing: Research, Theory, Practice promotes and disseminates contemporary drawing practice and research in its current cultural and disciplinary diversity. The journal encourages pluralist forms of discourse, inviting contributions that present drawing practice as performance, as a place of production, as discursive exploration, as a place of conception or as cognitive process.

\section{Editors}

Adriana Ionascu Ulster University

School of Art

a.ionascu@ulster.ac.uk 
Copyright of Book 2.0 is the property of Intellect Ltd. and its content may not be copied or emailed to multiple sites or posted to a listserv without the copyright holder's express written permission. However, users may print, download, or email articles for individual use. 